\title{
A Methodology Proposal for Selecting the Optimal Location for Small Hydropower Plants
}

\author{
Goran JEFTENIĆ, Andrija RAŠETA*, Srđan KOLAKOVIĆ, Milena PANIĆ, Slobodan KOLAKOVIĆ, Vladimir MANDIĆ
}

\begin{abstract}
The hydropower potential in the Republic of Serbia, as the most important renewable energy source, has been estimated at around $17000 \mathrm{GW} \cdot \mathrm{h}$ per year, where approximately $2000 \mathrm{GW} \cdot \mathrm{h}$ could be obtained from small hydropower plants (SHP). Small hydropower plants in Serbia currently produce $150 \mathrm{GW} \cdot \mathrm{h}$. Accordingly, the share of the electricity production from small hydropower plants in the total electricity production in Serbia is too small. The paper presents a model for the selection of optimal locations for small hydropower plants, which includes an ecological criterion, along with technical and economic criteria. The ecological criterion is eliminatory, i.e. those parts of the watercourse that border on or pass through protected natural assets are not taken into account when considering potential optimal locations for SHPs. All technical and economic criteria are included in the calculation of the weighted arithmetic mean with the aim of determining the optimal position for the construction of small hydropower plants. The model is implemented in the SHPOP software and its application is demonstrated on five watercourses in Southeastern Serbia.
\end{abstract}

Keywords: optimal position; optimization software; renewable energy sources; small hydropower plants; sustainable energy

\section{INTRODUCTION}

The attitude that the use of fossil energy sources (RES) should be reduced and that the share of alternative, environmentally friendly and justified energy sources in the global energy balance should increase has gained importance [1]. Renewable energy sources are considered to have a lower impact on the environment than the conventional energy sources from fossil fuels [2] due to reduced greenhouse gas emissions. As highlighted in [3], by adopting the 20-20-20 targets in 2007, the European Union set goals towards combating climate change and increasing the deployment of energy from RES. These goals have become even more ambitious for the 2021-2030 period, targeting a $40 \%$ cut in greenhouse gas emissions, $32 \%$ share for renewable energy and $32.5 \%$ improvement in energy efficiency [4].

Hydropower has become the fastest developing RES in the world, and the largest contributor of its kind to power generation, very popular in both developed and developing countries [2].

The utilization of hydropower potential involves the construction of large and small hydropower plants, which are not equally acceptable options in many countries. Since large hydropower projects have major negative social, economic and environmental impacts, general opinion is that small hydropower plants seem to be a more acceptable solution [6]. According to the European Small Hydropower Association (ESHA), a small hydropower plant is a power plant with a capacity of up to $10 \mathrm{MW}$ [7].

Although small hydropower plants are perceived as an "environmentally benign" [5] and sustainable solution, the potential negative effects of their construction and functioning should not be neglected [2]. These effects are primarily related to the environment, namely water quality, biodiversity, the passage of aquatic species, pest species, erosion and sedimentation [2], but they may also have implications on the social and economic level [3].

Many authors have discussed the problem of selecting an optimal location for the construction of small hydropower plants. It has been found that detailed spatial planning is necessary in order to meet the sustainability principle and its three main dimensions: social, economic and environmental [9].
One of the reasons for exploring potential locations for the construction of small hydropower plants is the need to electrify rural areas in less developed countries. These possibilities were analyzed by the authors of [10], who studied the influence of the social environment and involved the public into their research through questionnaires, seeking to raise the social awareness of this problem. The explored area was the Nan River basin, Thailand, and the research covered four aspects: engineering, economic, ecological and social aspects. However, in [11], the authors managed to narrow the choice of potential locations for the construction of small hydropower plants from 75 to 10 in the Lorestan Province, Iran, using only economic and social factors. The authors of [12] included both factors, i.e. they based their research into the electrification of rural areas in East Africa on nonnetworked small hydropower plants in Tanzania. They analyzed the concepts of electrification, seeking to establish relationships between new and already existing technologies, participants, resources and institutions. A similar study was conducted in Petralia Sottana on Sicily, Italy [13], where old and unused hydropower plants were analyzed in terms of feasibility. It was planned to restore and upgrade the oldest Sicilian hydropower plant so that it could meet modern requirements and the needs of a modern society. The paper [14] proposed a methodology for the exploration of potential locations for small hydropower plants in India relying on remote sensing data, normally used to map water sources, settlement patterns, vegetation and forest and snow cover. The analysis did not include the factors of hydrological and economic analysis. In [8], the authors focused on location selection for small hydropower plants in terms of their environmental acceptability, the priority being placed on the preservation of ecosystems in England and Wales. The analysis did not include the river's tributaries, assuming that there was a unique path from the river mouth to any upstream location. The analysis presented in [15] was limited to the hydropower potential of wider areas in the context of identifying potential locations for the construction of small hydropower plants, taking into account the topographic and hydrological features of the terrain. This case study was conducted in New Brunswick in Canada. In [16], the authors used a multiple-criteria analysis for the selection of 
alternative locations for the construction of small hydropower plants, based on economic criteria; accordingly, the following factors were included: gross energy potential, geological characteristics of the site, access roads, distance from urban centers and consumers, construction and maintenance costs. The authors of the paper [17] investigated the existing small hydropower plants throughout Greece, taking into account technical and economic factors, to conclude that the main problems were bureaucratic in nature; they were accompanied with poor water resource management and, finally, the exaggerated presentation of the facilities proposed for construction. The status of hydropower potential throughout Europe is described using GIS (Geographic Information System) models developed to identify potential locations for new small hydropower plants. The proposed approach is based on altitude difference data and the river network, supplemented with hydrological data derived from the flood forecasting model and flood risk assessment including climate change scenarios [18]. The authors of the paper [19] developed a software tool in order to determine the feasibility of small hydropower projects in Cameroon. The paper [20] presents a methodology for determining the potential of alternative hydropower locations, taking into account technical and economic criteria in a larger geographic area, using digital elevation maps (DEM) as input and ArcGIS. The methodology enables determining the lists of alternative locations for hydropower plants in the observed area. In the paper [21], the authors used this methodology to study the hydropower potential of the Kopili River Basin, India. SWAT2000 and GIS were used to determine potential locations based on the following three criteria: the order of stream, bottom gradient, and the minimum hydropower site interval of 500 $\mathrm{m}$. The research was limited to the influence of topographic and hydrological factors on location selection for the construction of small hydro power plants. The application of this methodology is presented in [22], where most of the 79 identified sites with a suitable altitude difference were eliminated from the selection due to a small width of the basin, which resulted in a considerably smaller final hydropower potential (below $100 \mathrm{~kW}$ ). Furthermore, [23] presents a GIS-based research for the purpose of constructing small hydro power plants in Korea. A multiple-criteria analysis including topographic, hydrological and environmental factors was applied. The main goal of the research was to identify potential sites before selecting the most favourable ones. Criteria relating to economic efficiency, site availability and distance to the electric grid were not taken into consideration.

Keeping in mind the geomorphological and hydrological characteristics of the terrain, the hydropower potential of the Republic of Serbia is estimated at $31000 \mathrm{GW} \cdot \mathrm{h}$ per year, out of which $17000 \mathrm{GW} \cdot \mathrm{h}$ can be technically exploited [24]. The major active hydropower plants use about $10000 \mathrm{GW} \cdot \mathrm{h}$ of the total hydropower potential. The remaining potential, amounting to $7000 \mathrm{GW} \cdot \mathrm{h}$, could be used if large $(75 \%)$ and small $(25 \%)$ hydropower plants were constructed. The potential of small water courses that could be used for the installation of small hydropower plants reaches 0.4 million tonne oil equivalent or $3 \%$ of the total potential of renewable sources in the Republic of Serbia. Most mountains in the Republic of Serbia are rather rich in water, with steep streams at short intervals, which ensures favourable conditions for exploitation. Although the Republic of Serbia has favourable conditions for the construction of small hydropower plants, in terms of the position of rivers, topography and hydrology, the potential for electric power production is insufficiently exploited [25]. In this respect, it is very important to analyze and explore potential areas and favourable locations in specific watercourses suitable for the construction of small hydropower plants.

The primary goal of this paper is to propose a model for selecting the optimal locations for small hydropower plants based on technical, economic and ecological criteria. Its timing is not coincidental, as it appears at the moment when both the Republic of Serbia and the EU Member States are making a strong shift towards the production of electric power from renewable energy sources. The main shortcoming in planning the construction of small hydropower plants is the model for determining their optimal location. Along with proposing a method for selecting the optimal location, the paper offers a software tool developed during the research, the basic purpose of which is to quickly determine the optimal locations for the construction of small hydropower plants based on the above-mentioned criteria.

\section{METHODOLOGY}

In order to perform the analysis of the selected watercourses, a digital terrain model (DTM) has been created, relying on the LIDAR surveying method. Based on the DTM, geographic and hydrological data have been determined: the surface of the basin, the altitude difference and the slopes between nodes along a watercourse and the coordinates of potential locations for small hydropower plants. Field models have been generated in the resolutions of $25 \mathrm{~cm}$ for potential locations of small hydro power plants, $1 \mathrm{~m}$ for river valleys, $5 \mathrm{~m}$ for river corridors and $10 \mathrm{~m}$ for the entire basin. Each watercourse has been divided into distinct sections by defining nodes, where each node represents a potential site for intake or a powerhouse of a small hydropower plant. The nodes of the model have been positioned along the watercourse, so that each node in the digital terrain model corresponds to a portion of the basin specifically assigned to it. At a later stage of the analysis, the values of the average annual flow rates for all nodes along the watercourse have been determined individually, based on the isoline map of the average annual specific discharge, provided by the Republic Hydrometeorological Institute of Serbia. The average annual flow rate is the sum of the product of the value of the specific discharge isoline module and the surface of the basin between the two adjacent isolines. The spillway overflow, as well as the minimum sustainable flow rate, have been assumed depending on the morphological and hydrological characteristics of the basin. The value of $20 \%$ of the average annual flow rate has been taken as the rate of the water spilling over the intake and the minimal sustainable flow rate to be ensured in the riverbed downstream from the water intake. The installed flow rate that a small hydropower plant can use in normal operation has been determined based on the average annual flow rate and the correction coefficient, 
taking into account the facility's throughput. The value of the correction coefficient has been taken to be 1.5 [26]. Three types of turbines (Pelton, Kaplan, Francis) have been used in this research to meet the requirement that the maximum efficiency be achieved, i.e. the maximum utilization of the available flow rate and slope, involving minimal investment.

\subsection{Software for the Automatic Selection of the Optimal Locations for Small Hydropower Plants}

Site analysis has been conducted for each watercourse individually, using the Small Hydro Power Plant Optimum
Position software (SHPOP, Fig. 1), developed by the authors of this study for research purposes using the JAVA programming language.

Each possible node combination in the watercourse has been analyzed based on technical, economic and ecological criteria and the combinations of nodes have been ranked based on the weighted arithmetic mean. For each individual combination of nodes, the installed capacity of the turbine and generator, the average electric power capacity, and the annual electric power production have been determined.

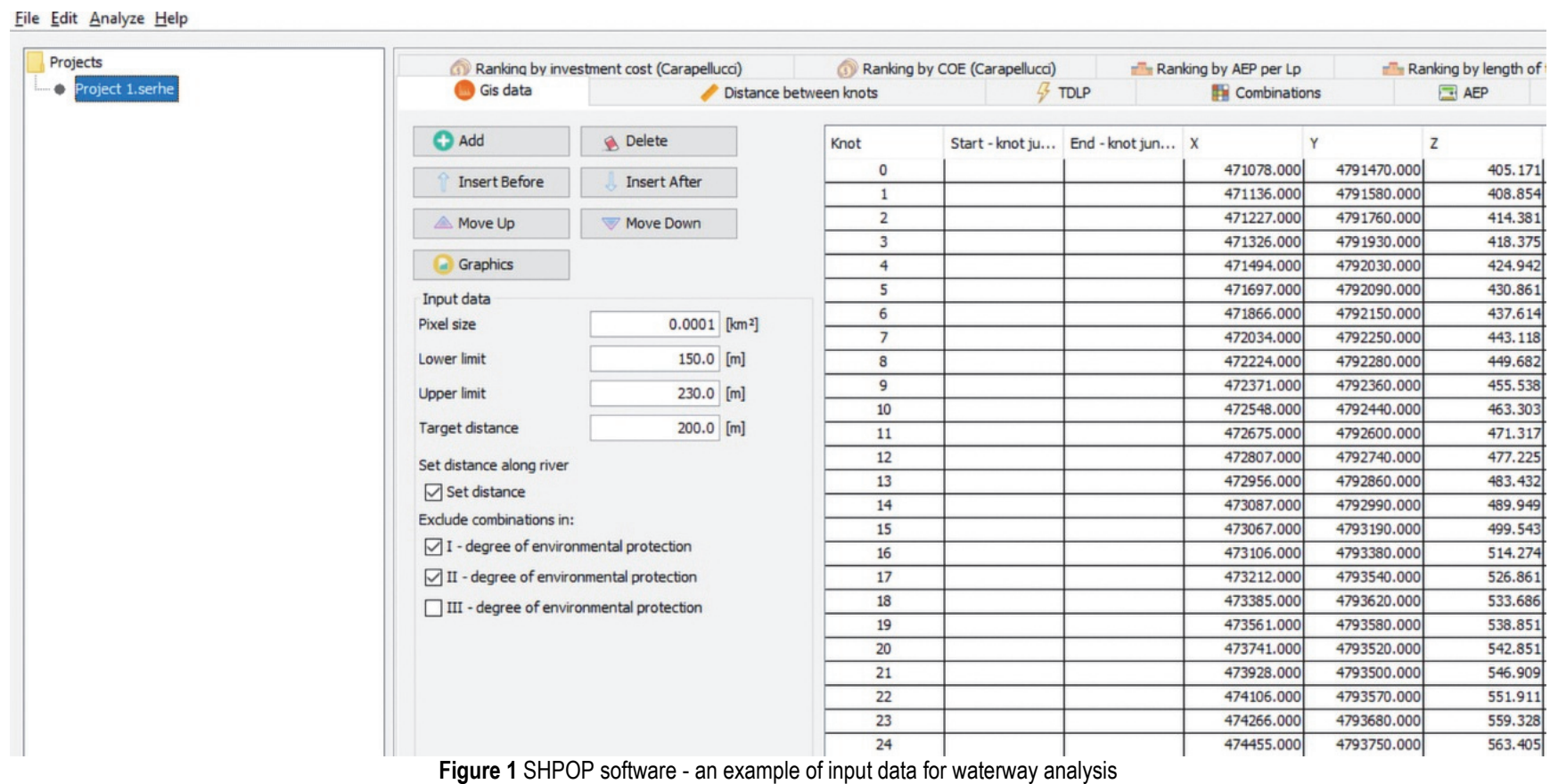

\subsection{Technical Criteria \\ 2.2.1 Installed Flow Rate}

The installed flow rate is the main factor affecting the capacity of hydropower plants [27]. The combinations of nodes are ranked based on the installed flow rate in a descending order.

\subsubsection{Annual Electric Power Production}

This criterion indicates the total annual production of electric power. High annual energy production means high potential [27]. The combinations of nodes are ranked according to the estimated annual electric power production in a descending order. This criterion is equivalent to the criterion for ranking node combinations according to the installed power of small hydropower plants.

\subsubsection{The Length of the Transmission Line}

The length of the transmission line has a significant effect on the loss of electricity during transmission from the electric power generating site to the distribution system [27]. The ranking is performed according to the length of the transmission line in a descending order.

\subsubsection{The Ratio between the Annual Electric Power Production and Pipeline Length}

This ratio is a measure of the utilization of a river section in terms of the identification of the shortest part of the river with the greatest annual production of electric power. This criterion has been used to identify the steep sections of the watercourse with a high energy potential. The combinations of nodes were ranked according to this ratio in a descending order.

\subsection{Economic Criteria}

The total investment costs are divided into the costs of construction, the costs of hydromechanical equipment, the cost of electromechanical equipment, the costs of connecting to the distribution network and other costs (administrative, purchase, project-related, supervision) [28]. In this paper, two methods for estimating investment cost have been applied.

The first method for estimating investment cost is based on the value of the investment costs for small hydropower plants built in the Republic of Serbia. The model includes the costs for small hydropower plants with small, medium and large slopes and all associated costs (water intake, pipeline, electromechanical equipment, 
turbines, powerhouse, as well as the value of all works related to the construction and installation of facilities, design development, administrative costs). The cost of the design development and administrative costs are expressed as a percentage of the total costs. The model has been devised over a long period and is constantly being updated to remain applicable. The interdependence between the investment cost and the installed power of a small hydropower plant is shown in Fig. 2.

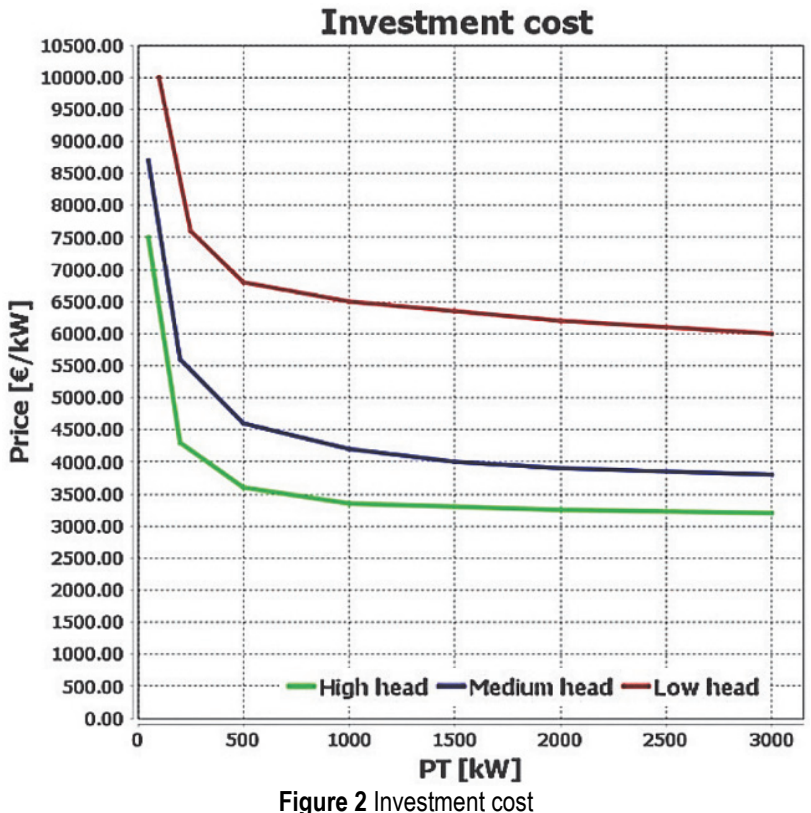

Another method for estimating investment cost is proposed in [29]. The average investment cost per unit of installed power of a small hydropower plant is shown in Fig. 3.

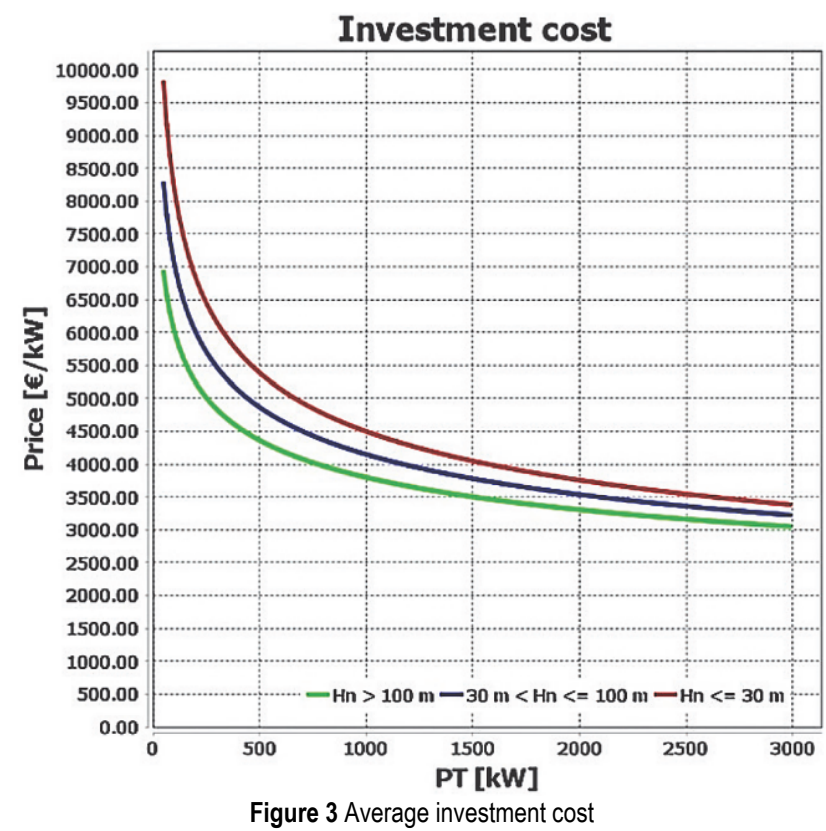

Along with the assessment of the investment cost, this study also presents an assessment of the investment cost accompanied with the costs of maintaining and exploiting a small hydropower plant for a period of 30 years [29]. The price of electric power produced is shown in Fig. 4.

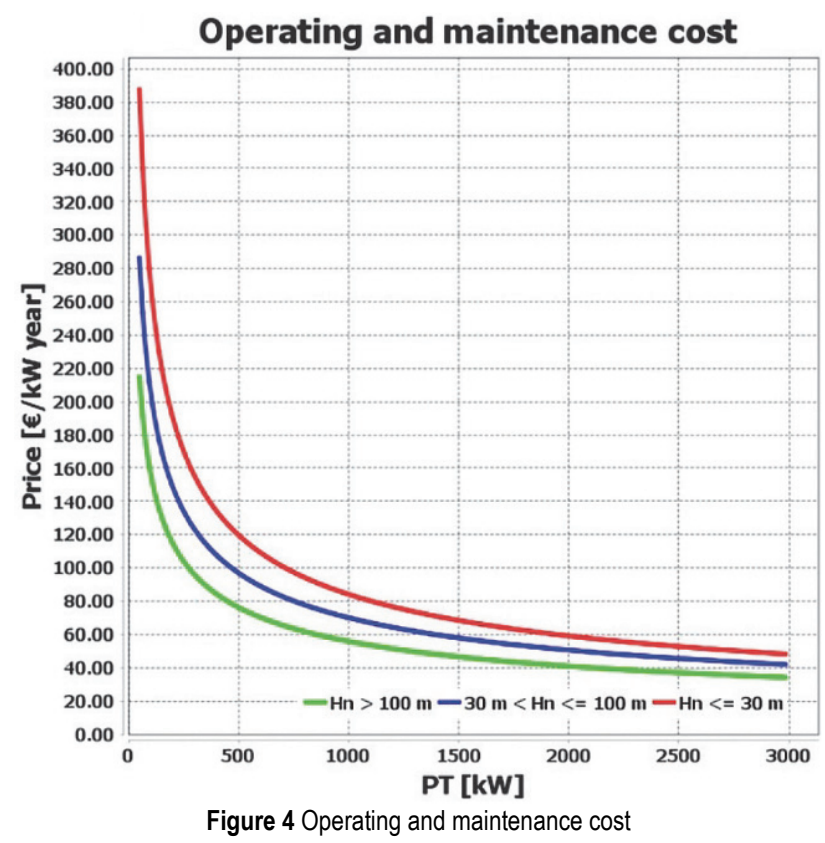

\subsection{Ecological Criterion}

The ecological criterion implemented in this model includes three levels of the protection regime defined in accordance with the Regulation on Protection Regimes [30]. The first-level protection regime means that a part of a watercourse or the entire watercourse is located within a protected area. If a watercourse is located near the protected area, it is under the second level of protection, whereas in all other cases, watercourses are under the third level of protection.

The level of protection that applies to an analyzed node combination corresponds to the highest level of protection that applies to an individual node in the combination. The node combinations where at least one node falls under the first-level protection regime are excluded from further consideration. The nodes combination that are further analyzed are equal to each other from the aspect of ecological criteria.

\subsection{The Selection of the Optimal Location for a Small Hydropower Plant}

For each individual combination of nodes, the previously described criteria (technical, economic and ecological) can be combined using the weighted arithmetic mean $C$ according to the formula:

$$
C=\frac{\sum_{i=1}^{n} w_{i} x_{i}}{\sum_{i=1}^{n} w_{i}}
$$

where: $n$ - total number of criteria, $w_{i}$ - weight of the $i$ criterion and $x_{i}$ - rank value of the $i$ criterion.

After determining the weighted arithmetic means for each node combination individually, all combinations in the observed basin are ranked. The optimal node combination, i.e. the optimal location for the construction of a small hydropower plant is the one with the smallest 
weighted arithmetic mean. In this study, all criteria have been assigned the same weight when calculating the weighted arithmetic mean, i.e. the weight share of all criteria has been the same.

\section{ANALYZED WATERCOURSES}

The research covered five watercourses in the territory of the Republic of Serbia (Fig. 5). The analyzed watercourses are mutually independent and belong to the Nisava river basin in the southeastern part of the Republic of Serbia.

The Zvonačka River is located in the southeastern part of the Republic of Serbia (Fig. 6a). The watercourse length is approximately $12.5 \mathrm{~km}$, whereas the total surface of the basin is approximately $75.475 \mathrm{~km}^{2}$. Nodes $14-63$ for the Zvonačka River fall under the third level of protection, whereas nodes $0-13$ belong to the second level of protection. The nodes under the second level of protection are located in the immediate vicinity of the Jerma Special Nature Reserve in the Republic of Serbia.

The Kutinska River is located in the southeastern part of the Republic of Serbia in the Nišava District (Fig. 6b). The watercourse reaches approximately $40 \mathrm{~km}$ in length. The total surface of the river basin is about $232 \mathrm{~km}^{2}$. The basin of the Kutinska River falls under the third level of protection.

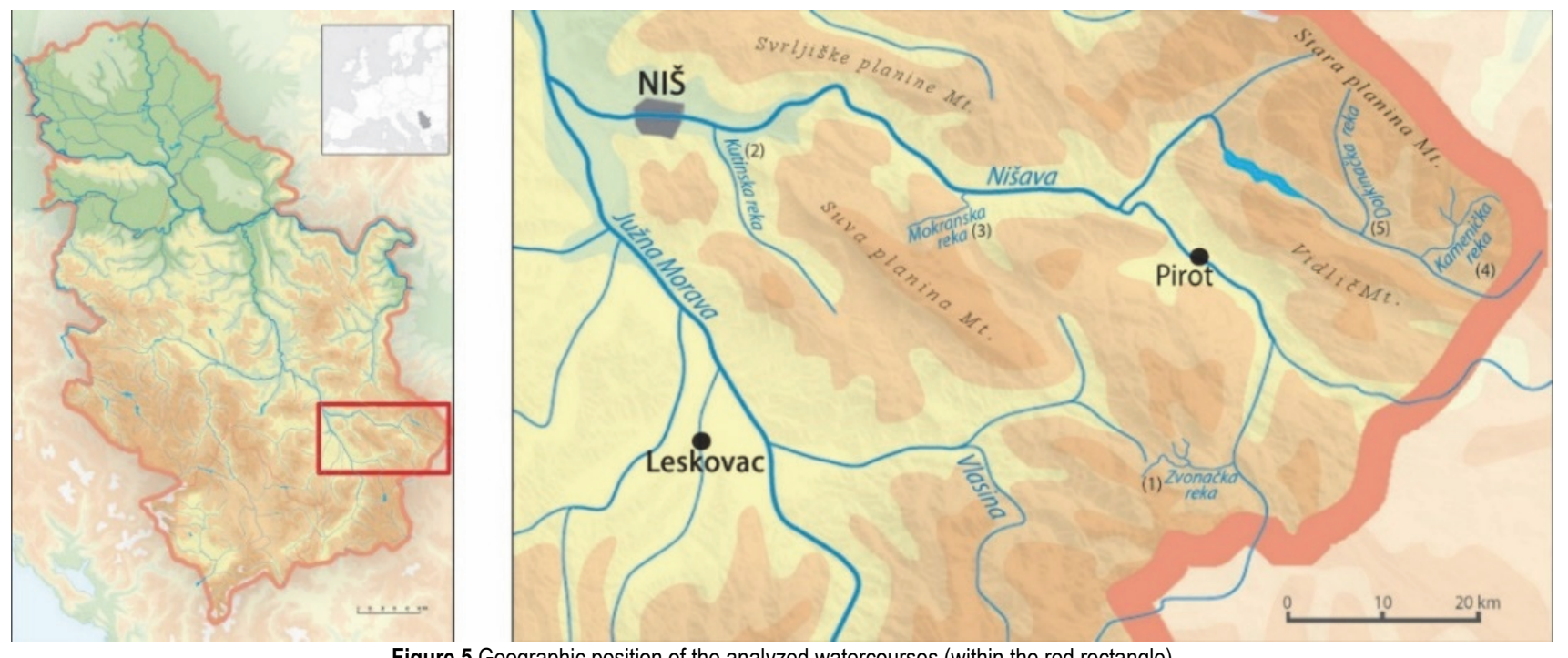

Figure 5 Geographic position of the analyzed watercourses (within the red rectangle)
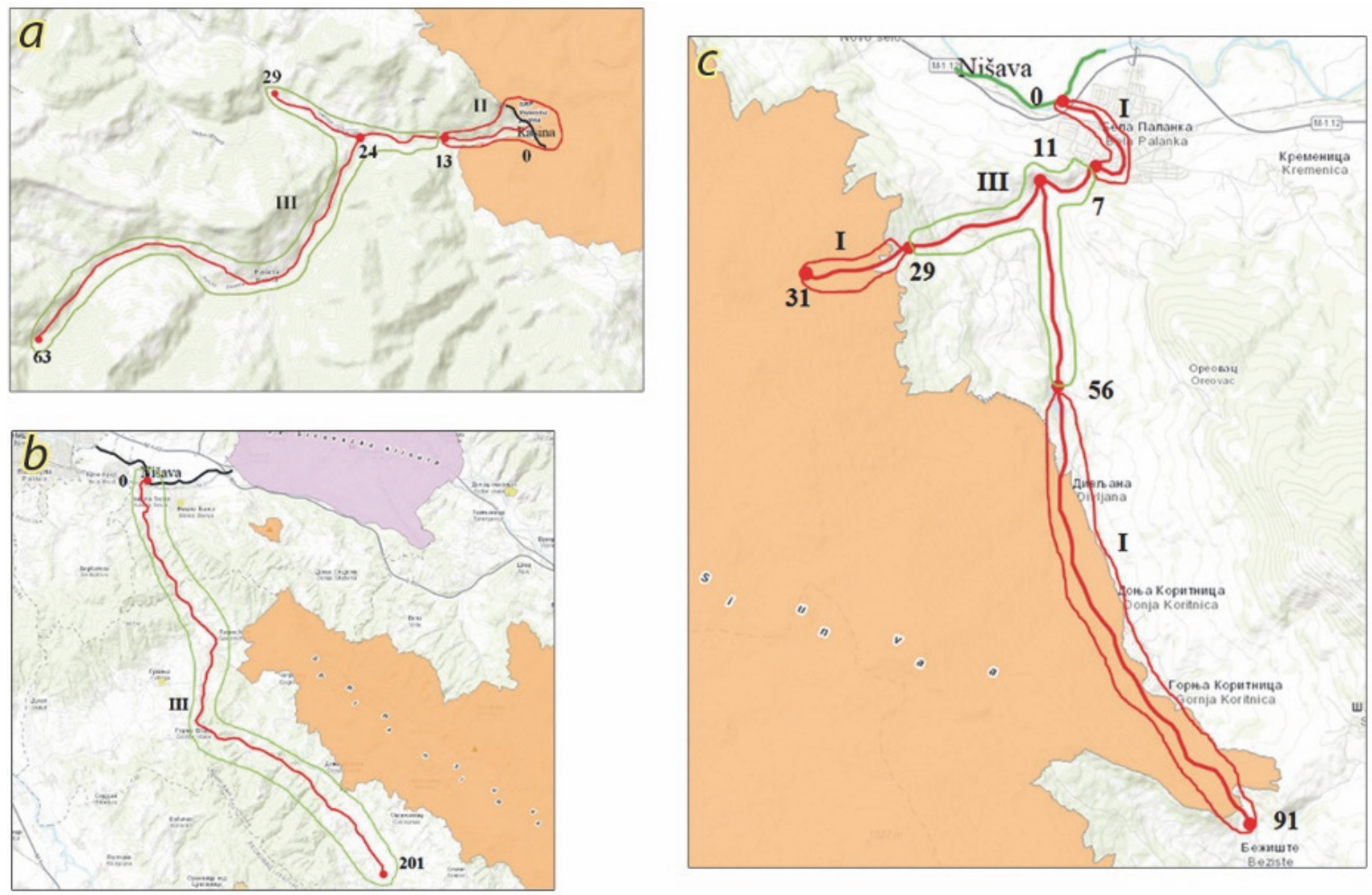

Figure 6 The position of the analyzed watercourses 

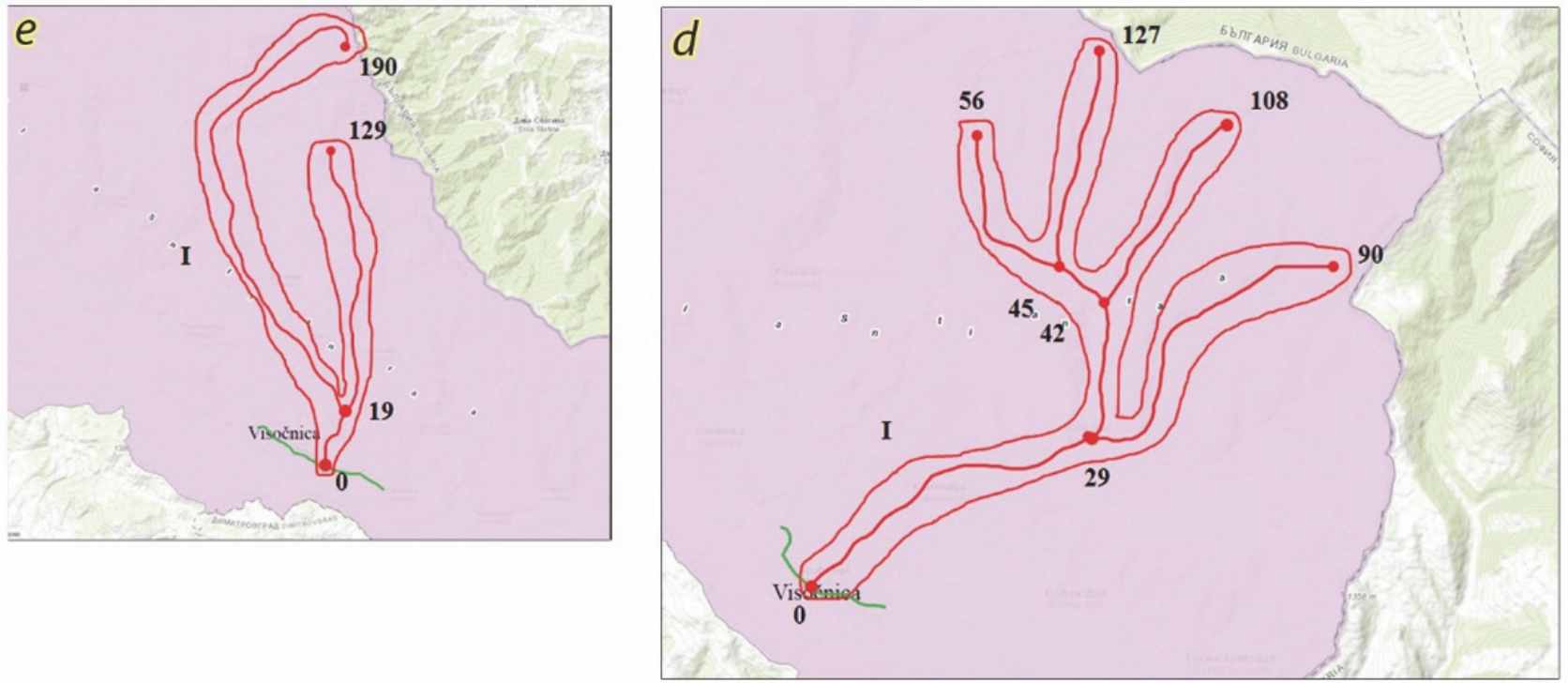

Figure 7 The position of the analyzed watercourses (first level of protection - pink surface)

The Mokranska River is located in the southeastern part of the Republic of Serbia in the Pirot District (Fig. 6c). The length of the Mokranska River is approximately 18 $\mathrm{km}$, whereas the total surface of the basin is about $127 \mathrm{~km}^{2}$. Nodes 0-7, 29-31, and 56-91 for the Mokranska River fall under the first level of protection, whereas nodes 7-29 and 7-56 belong to the third level of protection. The nodes under the first-level protection are partly located in an inhabited place and partly within the Suva Planina National Park.

The Kamenička River is located in the southeastern part of the Republic of Serbia (Fig. 7d). Together with all tributaries, the river reaches approximately $24 \mathrm{~km}$ in length, whereas the total surface of the basin is about $64 \mathrm{~km}^{2}$. The entire river course is located in an area under the first level of protection (pink surface), i.e. in the Stara Planina National Park.

The Dojkinačka River is located in the southeastern part of the Republic of Serbia, in the Pirot District (Fig. 7e). The total surface of the river's basin is approximately $137 \mathrm{~km}^{2}$. The entire course of the Dojkinačka River is located in an area under the first level of protection (pink surface), i.e. within the Stara Planina National Park.

As the Kamenička and Dojkinačka rivers are located in an area under the first level of protection, the construction of small hydropower plants is not allowed.

For all of the described basins, the $X, Y$ and $Z$ coordinates of nodes, the corresponding basin surfaces $A_{i}$ and the average specific annual discharges $q_{i}$ were defined in the GIS model. The input parameters used in the analysis of the basins are given in Tab. 1.

Table 1 The input data for the ranking of node combinations

\begin{tabular}{|l|c|}
\hline \multicolumn{1}{|c|}{ Parameter } & Value \\
\hline$k_{\mathrm{sr}}$ (coefficient of correction of the installed flow) & 1.50 \\
\hline$k_{\mathrm{dot}}$ (minimum sustainable flow coefficient) & 0.20 \\
\hline$k_{\mathrm{of}}$ (overflow coefficient) & 0.20 \\
\hline$\eta_{\mathrm{T}}$ (coefficient of useful effect of turbine) & 0.90 \\
\hline$\eta_{\mathrm{G}}$ (coefficient of useful effect of generator) & 0.92 \\
\hline$l_{\text {max }}$ (maximum length between intake and power house) & $4.0 \mathrm{~km}$ \\
\hline$P_{\mathrm{T}, \text { min }}$ (minimum installed power for the SHP) & $100.0 \mathrm{~kW}$ \\
\hline$\lambda_{1}$ (line loss; high head - more than 100 m; long pipeline) & 0.93 \\
\hline$\lambda_{2}$ (line loss; mean head - 30 m to 100 m; short pipeline) & 0.95 \\
\hline$\lambda_{3}$ (line loss; low head - up to 30 m; short pipeline) & 0.97 \\
\hline$w$ (for all analyzed criteria; determined by the authors) & 1.00 \\
\hline
\end{tabular}

\section{$4 \quad$ RESULTS AND DISCUSSION}

Relying on the SHPOP software, all possible node combinations have been determined for each analyzed water course; the optimal node combinations are shown in Fig. 8. The first node in an optimal combination defines the position of the powerhouse, whereas the second node defines the position of the water intake. Tab. 2 presents the optimal node combinations for each criterion individually, as well as the optimal combinations according to the weighted arithmetic mean for the Zvonačka River (Fig. 6a), Kutinska River (Fig. 6b) and Mokranska River (Fig. 6c). As the Kamenička (Fig. 7d) and Dojkinačka River (Fig. 7e) are located in an area under the first level of protection, where the construction of small hydropower plants is not allowed, optimal node combinations have not been determined for these rivers.

The obtained results presented in Tab. 2 indicate that the optimal locations (node combinations) for small hydropower plants vary depending on the type of criteria applied. When the economic criteria are applied, the optimal locations are grouped in one zone for each watercourse and they are in agreement with the optimal locations determined based on the technical criteria, according to the installed power. The reason for this lies in the fact that the investment costs for the construction, operation and maintenance of small hydropower plants is directly related to the installed power [29]. The optimal locations determined using solely the technical criteria vary for each watercourse because geographic and hydrological parameters, which are included in the technical criteria, are changing along watercourses.

The percentage of zones where the construction of small hydropower plants is allowed (Fig. 9) has been determined for each watercourse individually based on the ecological criterion. The Zvonačka River partly falls under the second and third levels of protection (Fig. 6a), and the Kutinska River (Fig. 6b) is fully under the third level of protection; accordingly, it is possible to identify the optimal locations for the construction of small hydro power plants all along their courses. As the Dojkinačka (Fig. 7e) and Kamenička rivers (Fig. 7d) run in their full length through the StaraPlanina National Park, falling under the 
first level of protection, the construction of small hydropower plants on these watercourses is not allowed. Parts of the Mokranska River are located in an urban area and the Suva Planina National Park, due to which the construction of small hydropower plants is not allowed, as those sections of the watercourse fall under the first level of protection (Fig. 6c). The rest of the watercourse is under the third-level protection; accordingly, it is possible to use approximately $21 \%$ of the total number of possible combinations to determine the optimal combination. Due to the limitations set by the ecological criterion, it would be possible to use only $44.2 \%$ of all possible locations for small hydropower plants in the analyzed watercourses.

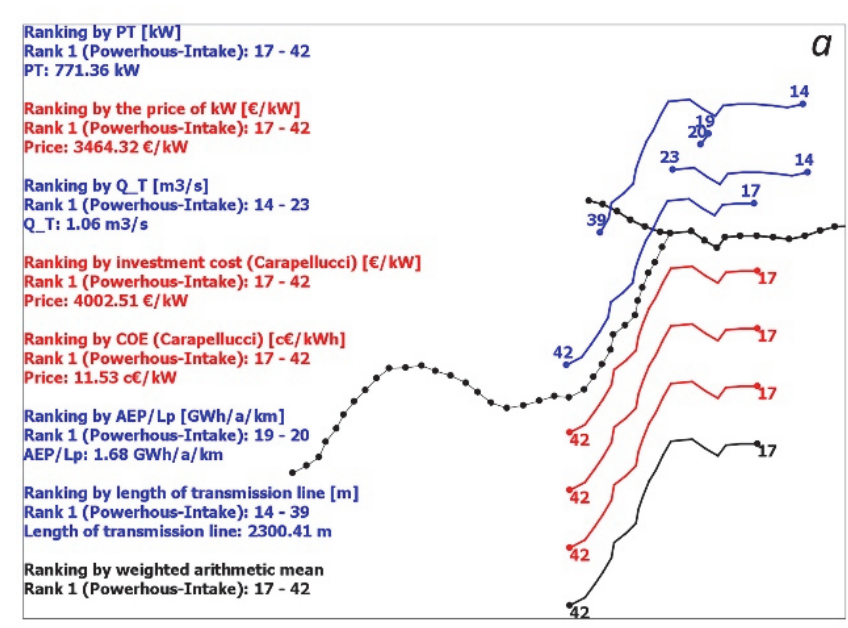

Ranking by PT [kW]

Rank 1 (Powerhou

Rank 1 (Powerhous-Intake): 17 - 42

Ranking by the price of $\mathrm{kW}[\varepsilon / \mathrm{kW}]$

Ranking by $\mathrm{Q} T[\mathrm{~m} 3 / \mathrm{s}]$

Ranking by investment cost (Carapellucci) $[\epsilon / \mathrm{kW}]$ Price: $4002.51 € / \mathrm{kW}$

PT: $683.27 \mathrm{~kW}$-Intake): $87-108$

Ranking by the price of $\mathrm{kW}[\ell / \mathrm{kW}]$

Rank 1 (Powerhous-Intake): 87 - 108

Ranking by $Q_{-} T[\mathrm{~m} 3 / \mathrm{s}]$ Rank 1 (Powerhous-Intake): 0 - 11 Q T: $2.74 \mathrm{~m} 3 / \mathrm{s}$

Ranking by investment cost (Carapellucci) $[€ / \mathrm{kW}]$ Powerhous-Intake): 87 - 108

Ranking by $\operatorname{COE}$ (Carapellucci) [c $€ / \mathrm{kWh}$ ] Rank 1 (Powerhous-Intake): 87 - 108 Price: $15.36 \mathrm{c} € / \mathrm{kW}$

Ranking by AEP/Lp [GWh/a/ km] Rank 1 (Powerhous-Intake): 142 - 143 AEP/Lp: $2.63 \mathrm{GWh} / \mathrm{a} / \mathrm{km}$

Ranking by length of transmission line [m] (Pencthe 1 (Power Rank 1 (Powerhous-Intake): 87 - 108
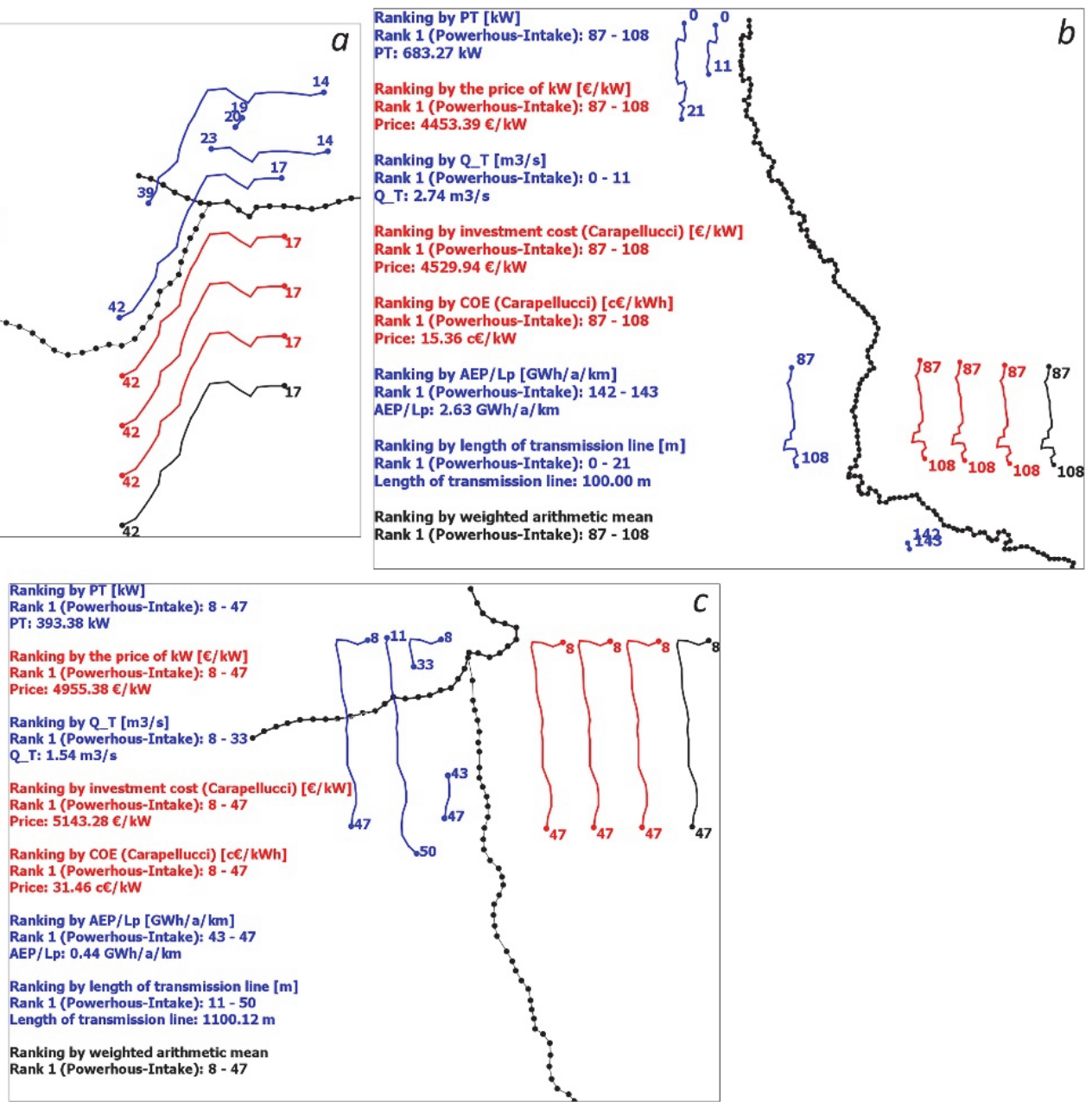

Figure 8 The distribution of optimal combinations of nodes for the analyzed watercourses

Table 2 Optimal combinations of nodes

\begin{tabular}{|c|c|c|c|c|c|c|c|c|}
\hline Watercourse & $\begin{array}{c}P_{\mathrm{T}} \\
/ \mathrm{kW}\end{array}$ & $\begin{array}{l}\text { Price per kW } \\
/ € / \mathrm{kW}\end{array}$ & $\underset{\mathrm{m}^{3} / \mathrm{s}}{Q_{\mathrm{T}}}$ & $\begin{array}{l}\text { Investment cost } \\
/ € / \mathrm{kW}\end{array}$ & $\begin{array}{l}\mathrm{COE} \\
/ \mathrm{c} € / \mathrm{kW}\end{array}$ & $\begin{array}{c}\mathrm{AEP} / \mathrm{L}_{\mathrm{p}} \\
/ \mathrm{GW} \cdot \mathrm{h} / \mathrm{a} / \mathrm{km}\end{array}$ & $\begin{array}{l}\text { Length of the } \\
\text { transmission line } \\
/ \mathrm{m}\end{array}$ & $\begin{array}{l}\text { Weighted } \\
\text { arithmetic } \\
\text { mean }\end{array}$ \\
\hline Zvonačka River & $17-42$ & $17-42$ & $14-23$ & $17-42$ & $17-42$ & $19-20$ & 14-39 & $17-42$ \\
\hline Kutinska River & $87-108$ & $87-108$ & $0-11$ & $87-108$ & $87-108$ & $142-143$ & $0-21$ & $87-108$ \\
\hline Mokranska River & $8-47$ & $8-47$ & $8-33$ & $8-47$ & $8-47$ & $43-47$ & $11-50$ & $8-47$ \\
\hline Kamenička River & 1 & 1 & 1 & 1 & 1 & 1 & 1 & 1 \\
\hline Dojkinačka River & 1 & 1 & 1 & 1 & 1 & 1 & 1 & 1 \\
\hline
\end{tabular}

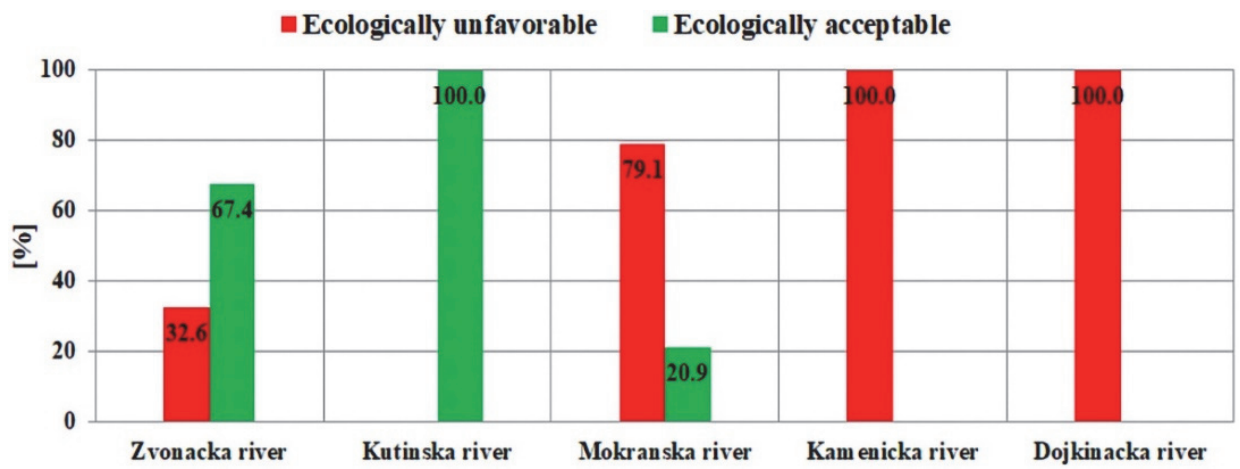

Figure 9 Percentage of ecologically acceptable and ecologically unfavourable locations for small hydropower plants according to the ecological criterion, for each watercourse individually 


\section{CONCLUSION}

The construction of small hydropower plants is inevitably associated with a conflict between the need for renewable energy production, on the one hand, and the striving to preserve the ecosystem, on the other. These installations inevitably disturb watercourses to some extent, but this effect is considerably less harmful than the effects of the exploitation of other energy sources.

The main problem associated with the construction of small hydropower plants is determining the optimal location in the watercourse. The paper presents an optimization model for selecting locations for small hydropower plants, implemented in the SHPOP software. The proposed model includes an ecological criterion, which is the eliminatory criterion in the process of selecting watercourses for the construction of small hydropower plants, as well as technical and economic criteria, which determine the optimal location for a small hydropower plant in the selected watercourse. Furthermore, the proposed model can be applied without limitations to any watercourse where the construction of small hydropower plants is allowed.

In order to include all of the applied technical and economic criteria, the weighted arithmetic mean is used in determining the optimal location. All possible combinations of nodes are ranked for each criterion, individually. For each combination of nodes a weighted arithmetic mean is determined by combining ranks in all technical and economic criteria applied in the analysis. The combination of nodes with the smallest weighted arithmetic mean indicates the optimal location for a small hydropower plant in a watercourse.

Based on the analysis of five watercourses, it may be concluded that the optimal locations identified based on the economic criteria correspond to those identified based on the installed power (technical criterion). The reason for this lies in the fact that the construction, maintenance and operation costs are directly related to the installed power.

Further research may develop in two directions. The first direction would involve an analysis of the impact of the same type of criteria on the optimal solution: all economic criteria would be classified into one group and all technical into another; all criteria in one group would have the same weighting coefficient. The second direction would be to determine the impact of each criterion on the optimal solution by varying the corresponding weighting coefficients, since the model enables assigning different weighting coefficients. The third direction of further research would refer to the ecological criterion and its influence on the selection of the optimal position for the construction of small hydropower plants. This implies the introduction of ecological sub-criteria that would be applied for ranking combinations of nodes in zones in which the construction of small hydropower plants is allowed according to the ecological criterion.

\section{Acknowledgements}

The research has been conducted within the scientific research project "A comprehensive approach to improvement of interdisciplinary researches in construction education and science", developed at the
Department of Civil Engineering and Geodesy, Faculty of Technical Sciences, University of Novi Sad, Serbia.

\section{REFERENCES}

[1] Panić, M., Urošev, M., Milanović Pešić, A., \& Miljanović, D. (2014). Hydroelectricity and Power Electronics Environmental Impacts, Emerging Technologies and Challenges. New York, NY: Nova Science Publishers, Inc.

[2] Botelho, A., Ferreira, P., Lima, F., Costa Pinto, L., \& Sousa, S. (2017). Assessment of the environmental impacts associated with hydropower. Renewable and Sustainable Energy Reviews, 70, 896-904. https://doi.org/10.1016/j.rser.2016.11.271

[3] Wagner, B., Hauer, C., Schoder, A., \& Habersack, H. (2015). A review of hydropower in Austria: Past, present and future development. Renewable and Sustainable Energy Reviews, 50, 304-3014. https://doi.org/10.1016/j.rser.2015.04.169

[4] European Commission; Energy, Climate change, Environment; Climate Action; EU Action; Climate strategies $\&$ targets. Retrieved from https://ec.europa.eu/clima/policies/strategies/2030 en

[5] Lenzen, M. (2010). Current state of development of electricity-generating technologies: a literature review. Energies, 3, 462-591. https://doi.org/10.3390/en3030462

[6] Sharma, A. K. \& Thakur, N. S. (2017). Assessing the impact of small hydropower projects in Jammu and Kashmir: A study from north-western Himalayan region of India. Renewable and Sustainable Energy Reviews, 80, 679-693. https://doi.org/10.1016/j.rser.2017.05.285

[7] European Small Hydropower Association (ESHA) (2011). Current status of Small Hydropower development in the EU27. Retrieved from http://www.streammap.esha.be

[8] Ioannidou, C. \& O'Hanley, J. R. (2018). Eco-friendly location of small hydropower. European Journal of Operational Research, 264, 907-918. https://doi.org/10.1016/j.ejor.2016.06.067

[9] Garegnani, G., Sacchelli, S., Balest, J., \& Zambelli, P. (2018). GIS-based approach for assessing the energy potential and the financial feasibility of run-off-river hydropower in Alpine valleys. Applied Energy, 216, 709-723. https://doi.org/10.1016/j.apenergy.2018.02.043

[10] Rojanamon, P., Chaisomphob,T., \& Bureekul, T. (2009). Application of geographical information system to site selection of small run-of-river hydropower project by considering engineering/economic/environmental criteria and social impact. Renewable and Sustainable Energy Reviews, 13, 2336-2348. https://doi.org/10.1016/j.rser.2009.07.003

[11] Ghadimia, A. A., Razavi, F., \& Mohammadian, B. (2011). Determining optimum location and capacity for micro hydropower plants in Lorestan province in Iran. Renewable and Sustainable Energy Reviews, 15, 4125-4131. https://doi.org/10.1016/j.rser.2011.07.003

[12] Ahlborg, H. \& Sjöstedt, M. (2015). Small-scale hydropower in Africa: Socio-technical designs forrenewable energy in Tanzanian villages.Energy Research \& Social Science, 5, 20-33. https://doi.org/10.1016/j.erss.2014.12.017

[13] Gagliano, A., Tina, G.M., Nocera, F., \& Patania, F. (2014). Technical and Economic Perspective for Repowering of Micro Hydro Power Plants: A Case Study of an Early XX Century Power Plant. Energy Procedia, 62, 512-521. https://doi.org/10.1016/j.egypro.2014.12.413

[14] Dudhani, S., Sinha, A. K., \& Inamdar, S. S. (2006). Assessment of small hydropower potential using remote sensing data for sustainable development in India. Energy Policy, 34, 3195-3205. https://doi.org/10.1016/j.enpol.2005.06.011 
[15] Cyr, J. F., Landry, M., \& Gagnon, Y. (2011). Methodology for the large-scale assessment of small hydroelectric potential: Application to the Province of New Brunswick (Canada). Renewable Energy, 36, 2940-2950. https://doi.org/10.1016/j.renene.2011.04.003

[16] Mladineo, N., Margeta, J., Brans, J. P., \& Marechal, B. (1987). Multicriteria ranking of alternative locations for small scale hydro plants. European Journal of Operational Research, 31, 215-222. https://doi.org/10.1016/0377-2217(87)90025-7

[17] Kaldellis, J. K. (2006). The contribution of small hydro power stations to the electricity generation in Greece: technical and economic considerations. Energy Policy, 35, 2187-2196. https://doi.org/10.1016/j.enpol.2006.06.021

[18] Bódis, K., Monforti, K., \& Szabó, S. (2014). Could Europe have more mini hydro sites? A suitability analysis based on continentally harmonized geographical and hydrological data. Renewable and Sustainable Energy Reviews, 37, 794808. https://doi.org/10.1016/j.rser.2014.05.071

[19] Kengne-Signe, E. B., Bogno, B., Aillerie, M., \& Hamandjoda, O. (2019). Performance in Feasibility Studies of Micro Hydro Power Plants. New Software Development and Application Cases in Cameroon. Energy Procedia, 157, 1391-1403. https://doi.org/10.1016/j.egypro.2018.11.304

[20] Serpoush, B., Khanian, M., \& Shamsai, A. (2017). Hydropower plant site spotting using geographic information system and a MATLAB based algorithm. Journal of Cleaner Production, 152, 7-16. https://doi.org/10.1016/j.jclepro.2017.03.095

[21] Kusre, B. C., Baruah, D. C., Bordoloi, P. K., \& Patra, S. C. (2010). Assessment of hydropower potential using GIS and hydrological modeling technique in Kopili River basin in Assam (India). Applied Energy, 87, 298-309. https://doi.org/10.1016/j.apenergy.2009.07.019

[22] Setiawan, D. (2015). Potential Sites Screening for Mini Hydro Power Plant Development in Kapuas Hulu, West Kalimantan: a GIS approach. Energy Procedia, 65, 76-82. https://doi.org/10.1016/j.egypro.2015.01.034

[23] Yi, C. S., Lee, J. H., \& Shim, M. P. (2010). Site location analysis for small hydropower using geo-spatial information system. Renewable Energy, 35, 852-861. https://doi.org/10.1016/j.renene.2009.08.003

[24] Panić, M. et al. (2013). Small hydropower plants in Serbia: Hydropower potential, current state and perspectives. Renewable and Sustainable Energy Reviews, 23, 341-349. https://doi.org/10.1016/j.rser.2013.03.016

[25] Jovanović, B. \& Parović, M. (2009). State and development of small hydropower plants in Serbia, Belgrade: Jefferson Institute.

[26] Ristić, B. (1997). Hidroelektrane, JP Elektroprivreda Srbije, Beograd.

[27] Supriyasilp, T., Pongput, K., \& Boonyasirikul, T. (2009). Hydropower development priority using MCDM method. Energy Policy, 37, 1866-1875. https://doi.org/10.1016/j.enpol.2009.01.023

[28] Lee, H. C. \& Chang, C. T. (2018). Comparative analysis of MCDM methods for ranking renewable energy sources in Taiwan. Renewable and Sustainable Energy Reviews, 92, 883-896. https://doi.org/10.1016/j.rser.2018.05.007

[29] Carapellucci, R. et al. (2015). Techno-economic evaluation of small-hydro power plants: Modelling and characterisation of the Abruzzo region in Italy. Renewable Energy, 75, 398406. https://doi.org/10.1016/j.renene.2014.10.008

[30] Uredba o režimima zaštite ("Sl. glasnik RS", br. 31/2012). Retrieved from http://www.zzps.rs/novo/kontent/stranicy/zastita_prirode_o _zasticenim_podrucjima/uredba_rezimi_zastite.pdf

\section{Contact information:}

Goran JEFTENIĆ, Ass. MSc CE

Faculty of Technical Sciences, University of Novi Sad, Trg Dositeja Obradovica 6, 21000 Novi Sad, Serbia

E-mail: goran.jeftenic@uns.ac.rs

Andrija RAŠETA, PhD, Ass. Professor

(Corresponding author)

Faculty of Technical Sciences, University of Novi Sad

Trg Dositeja Obradovica 6, 21000 Novi Sad, Serbia

E-mail: araseta@uns.ac.rs

Srđan KOLAKOVIĆ, PhD, Full Professor

Faculty of Technical Sciences, University of Novi Sad

Trg Dositeja Obradovica 6, 21000 Novi Sad, Serbia

E-mail: kolak@uns.ac.rs

Milena PANIĆ, PhD, Research Associate

Geographical Institute "Jovan Cvijić", Serbian Academy of Sciences and Arts, Djure Jakšića 9, 11000 Belgrade, Serbia

E-mail: m.panic@gi.sanu.ac.rs

Slobodan KOLAKOVIĆ, PhD, Ass. Professor

Faculty of Technical Sciences, University of Novi Sad,

Trg Dositeja Obradovica 6, 21000 Novi Sad, Serbia

E-mail: kolakovic.s@uns.ac.rs

Vladimir MANDIĆ, Ass. MSc CE

Faculty of Mechanical and Civil Engineering, University of Kragujevac,

Dositejeva 19, 36000 Kraljevo, Serbia

E-mail: mandic.v@mfkv.kg.ac.rs 